\title{
Management of Alternaria Leaf and Pod Blight Diseases of Mustard through combination of Bio-Agents, Fungicides, Micronutrients and Cultural Operations in Bastar Plateau of Chhattisgarh
}

\author{
R.S. Netam*, S.C. Mukherjee, J.L. Salam and P.S. Netam
}

SG College of Agriculture \& Research Station, IGKV, Jagdalpur, Bastar (CG), India

*Corresponding author

\begin{abstract}
A B S T R A C T
Keywords

Alternaria blight,

Management, Bio-agent,

Fertilizer, Fungicide,

Micronutrient and

cultural practice

Article Info

Accepted:

10 October 2018

Available Online:

10 November 2018

Rapeseed-mustard accounts for 19.97 per cent of the total oilseeds production in India and it is one of the major contributors to Yellow Revolution. Their yield losses due to Alternaria blight was reported in the range of 10 to 70 per cent variable. The seed quality, seed size, colour and reduction of oil up to 10 per cent and seed germination ability is also adversely affected due to this disease in addition to quantities yield losses. Nine different treatment combinations of bio-agents, fungicides, micronutrients and cultural operations with a control were testing the effectiveness against the Alternaria leaf and pod blight of mustard in two consecutive crop seasons, 2011-12 and 2012-13. The integrated disease management (IDM) practice is used for reducing Alternaria leaf and pod blight and for sustaining higher yields of mustard. The use of $\mathrm{ZnO} 15 \mathrm{~kg} / \mathrm{ha}(\mathrm{SA})+$ Borax $10 \mathrm{~kg} / \mathrm{ha}(\mathrm{SA})$ + Sulphar as basal dose $+P$. flurescens $10 \mathrm{ml} /$ lit water (FS) against the recorded minimum disease severity and gave highest per cent disease control as compared to other treatments as $8.90,1.59$ per cent and $60.05,80.26$ per cent respectively.
\end{abstract}

\section{Introduction}

Rapeseed-mustard covers all Brassica spp. grown in the country including $B$. napus in the Himachal Pradesh state, foothills of Uttarakhand, Jammu \& Kashmir, some parts of Punjab state, B. rapa var yellow sarson in West Bengal and some parts of Bihar states with around $85 \%$ area dominated by $B$. juncea all over the country. Rapeseed-mustard is predominantly cultivated in Rajasthan (50\%), Uttar Pradesh (12.3\%), Haryana (11.2\%), Madhya Pradesh (9.8\%), Gujarat (6.5\%) and West Bengal (5.1\%) states of the country, which all together contribute $95 \%$ to the total national production of the crop. In India, Rapeseed-mustard is an important group of edible oilseed crops and contributed around $26.1 \%$ of the total oilseed production. Out of 57856 thousand tonnes of rapeseed-mustard seed produced over 30308 thousand ha in the world, India produced 5833 thousand tonnes from 5750 thousand ha (FAO, 2010). Mustard is one of most important and oldest known oil seed crop of subcontinent with global contribution of $28.3 \%$ acreage and $19 \%$ of production (Bandopandopadyay et al., 2013). The biotic stress of Alternaria leaf blight of mustard is most important and its causal agent is Alternaria brassicae. It has been reported 
from all the continents of the world and is one among the important diseases of mustard causing up to $47 \%$ yield losses. Fungus infect all parts of plant as leaves, pods, branches, pods and stem but the special target point of fungus are leaves and pods. Often lesions are produced on green leaves and during sever attack in pods seeds become shrivel and early ripening or shattering. Alternaria blight disease caused by Alternaria brassicae (Berk.) Sacc. \& A. brassicicola (Schw.). Alternaria blight disease severity varies with the microclimatic conditions at the particular location, application of fungicides at critical stages of 45 and 75 days after sowing for development of the disease has been reported to minimize losses due to the disease and increase benefit for the users (Meena et al., 2004). Mineral nutrition has long been recognized as an important component of disease management practices (Agrios, 2005). Soil applied sulphur was found to increase resistance against a variety of fungal pathogens on different crops (Klikocka et al., 2005). The problem is being addressed by application of combination of bio-againt, fungicides, micronutriant, and cultural practices for effective management of Alternaria blight of mustard. Potential of chemical fungicides, bio-agents for substituting the recommended chemical fungicides applied as soil application at the time of sowing and foliar spray at critical stages of 45, 75 days after sowing against the Alternaria blight disease were tested in the present study.

\section{Materials and Methods}

Field experiments were conducted in two successive post-monsoon (rabi) crop seasons (October - March) of 2011-12 and 2012-13 at farm of SG College of Agriculture and Research Station, Kumharawand, Jagdalpur District Bastar of Chhattisgarh State. Nine treatments with a control plot their only water spray were considered. Experiment was laid out in plots of $5 \times 3 \mathrm{~m}$ at $30 \times 15 \mathrm{~cm}$ spacing in randomized block design (RBD) with three replications using popular cultivar Varuna of Indian mustard as the test variety. Experimental plots in all the treatments recommended (NRCRM, 1999) dose of nitrogen (80 kg ha-1) and phosphorus (40 kg ha-1). Application of potash @ $40 \mathrm{~kg}$ and sulphur @ 20 kg ha-1 was carried out as basal dose at the time of sowing. Treatments applied like Tricoderma harzianum 10g/kg (Seed treatment) + Pseudomonas flurescens $10 \mathrm{ml} / 1$ water (Foliar spray); $\mathrm{ZnO} 15 \mathrm{~kg} / \mathrm{ha}$ (Soil application) + Borax $10 \mathrm{~kg} / \mathrm{ha} \quad$ (Soil application) + Sulphar as basal dose; Removal of three lower leaves; Ipridione + carbendazime $2 \mathrm{~kg} / \mathrm{ha}($ Seed treatment $)+$ carbendazime + mancozeb @ 0.2\% (Foliar spray) 2 sprays; $\mathrm{ZnO} 15 \mathrm{~kg} / \mathrm{ha}$ (Soil application) + Borax $10 \mathrm{~kg} / \mathrm{ha} \quad$ (Soil application) + Sulphar as basal + carbendazime + mancozeb @ 0.2\% (Foliar spray) 2 sprays; $\mathrm{ZnO} 15 \mathrm{~kg} / \mathrm{ha}$ (Soil application) +Borax 10kg/ha (Soil application) +Sulphar as basal dose + P. flurescens 10 $\mathrm{ml} / 1$ water (Foliar spray); Removal of three lower leaf + Rridomil MZ 72 WP@ 0.2\%(Foliar spray); Ipridione + carbendazime $2 \mathrm{~kg} / \mathrm{ha}$ (Sees treatment) + Removal of three lower leaves; Propiconazole@0.1\% (Seed treatment)+ (Foliar spray); with the control.

The treatments were applied as soil application and seed treatment before sowing of seed and foliar spray at known critical stages for Alternaria blight disease development i.e. 45 and 75 days after sowing. In all the experimental plots, randomly selected ten plants were tagged for observations. Percentage disease severity of Alternaria blight was recorded uniformly at all experimental plots on 10 randomly selected plants on leaves and pods using standard pictorial rating scale of Conn et al., (1990). The per cent disease control was worked out using the formula given by Abbott's (1925). 
Percentage reduction $=\mathrm{C}-\mathrm{T} / \mathrm{C} \times 100$, where, $\mathrm{C}$ is the population of control and $\mathrm{T}$ is the population of treated plots. The data were statistically analyzed using analysis of variance to determine the least significant difference $(\mathrm{p}<0.05)$.

\section{Results and Discussion}

Effect of different treatments combination of bio-againt, fungicides, micronutriant, and cultural practices was evaluated in field for reducing Alternaria leaf and pod blight of mustard causing by Alternaria brassicae. The Alternaria leaf blight severity was found to be significantly less in all treated plots over check. Among the different treatment combination of bio-againt, fungicides, micronutriant, and cultural practices, the treatment combination of $\mathrm{ZnO} 15 \mathrm{~kg} / \mathrm{ha}$ (Soil application) + Borax 10kg/ha (Soil application) + Sulphar as basal dose $+P$. flurescens $10 \mathrm{ml} / \mathrm{lit}$. water ( 1 foliar spray) 8.90 per cent pooled mean was recorded minimum disease severity of two successive postmonsoon (rabi) crop seasons, followed by $\mathrm{ZnO} 15 \mathrm{~kg} /$ (Soil application) + Borax 10kg/ha (Soil application)+ Sulphar as basal + carbendazime + mancozeb @ 0.2\% (2 foliar spray) 12.41 per cent and Ipridione + carbendazime $2 \mathrm{~kg} / \mathrm{ha}$ (Seed treatment) + carbendazime + mancozeb @ 0.2\% (2 foliar spray) 12.72 per cent and gave highest per cent disease control, 60.05 per cent followed by 44.28 and 42.89 per cent as compared to other treatments respectively (Table 1 ).

Table.1 Effect of different treatments combination of bio-agent, fungicides, micronutriant, and cultural practices against of Alternaria leaf blight of mustard during the year 2011-12 \& 2012-13

\section{\begin{tabular}{|c|}
\hline S. \\
\hline No. \\
\hline 1. \\
\hline 2. \\
\hline 3. \\
\hline 4. \\
\hline 5. \\
\hline
\end{tabular}}

6.

7.

8. Ipridione + carbendazim $2 \mathrm{~kg} / \mathrm{ha}$ (ST) + Removal of three lower leaves.

9. Propiconazole @ 0.1\% (ST) + (FS)

10. Control

\begin{tabular}{|c|c|c|}
\hline \multicolumn{3}{|c|}{ Percent disease severity of Alternaria } \\
\hline leaf blight
\end{tabular}

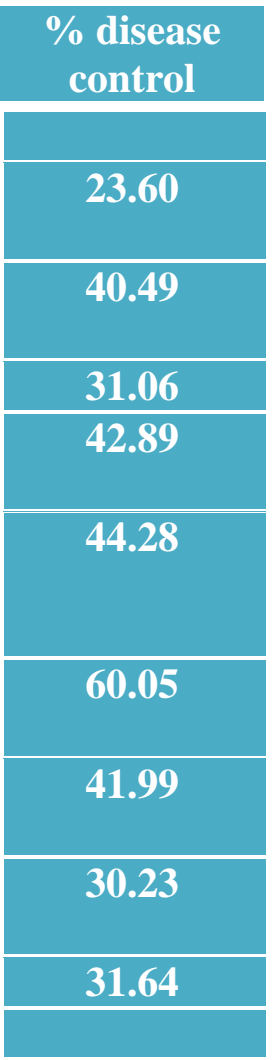
$\mathrm{CD}(\mathrm{P}=0.05)$ 1.84 3.33

Figures in parentheses are angular transformed values; ST: seed treatment; SA: Soil application; FS: foliar spray. 
Table.2 Effect of different treatments combination of bio-agent, fungicides, micronutriant, and cultural practices against Alternaria pod blight of mustard diseases during the year 2011-12 and 2012-13

\begin{tabular}{|c|c|c|c|c|c|}
\hline \multirow[t]{2}{*}{$\begin{array}{l}\text { S. } \\
\text { No. }\end{array}$} & \multirow[t]{2}{*}{ Treatments } & \multicolumn{3}{|c|}{$\begin{array}{l}\text { Percent disease severity of } \\
\text { Alternaria pod blight }\end{array}$} & \multirow[t]{2}{*}{$\begin{array}{c}\% \text { disease } \\
\text { control }\end{array}$} \\
\hline & & 2011-12 & $2012-13$ & $\begin{array}{c}\text { Mea } \\
\mathrm{n}\end{array}$ & \\
\hline 1. & $\begin{array}{l}\text { T. harzianum } 10 \mathrm{~g} / \mathrm{kg}(\mathrm{ST})+P \text {. flurescens } \\
10 \mathrm{ml} / 1 \text { water }(\mathrm{FS})\end{array}$ & $3.77(11.17)$ & $4.23(11.87)$ & 4.00 & 50.19 \\
\hline 2. & $\begin{array}{l}\mathrm{ZnO} 15 \mathrm{~kg} / \mathrm{ha}(\mathrm{SA})+\text { Borax } 10 \mathrm{~kg} / \mathrm{ha}(\mathrm{SA}) \\
+ \text { Sulphar as basal dose }\end{array}$ & $7.13(15.40)$ & $2.23(8.59)$ & 4.68 & 41.72 \\
\hline 3. & Removal of three lower leaves & $3.60(10.86)$ & $0.47(3.19)$ & 2.04 & 74.66 \\
\hline 4. & $\begin{array}{l}\text { Ipridione+carbendazim } 2 \mathrm{~kg} / \mathrm{ha}(\mathrm{ST})+ \\
\text { carbendazim+mancozeb @ } 0.2 \%(\mathrm{FS}) 2 \\
\text { sprays }\end{array}$ & $6.57(14.68)$ & $0.63(3.72)$ & 3.60 & 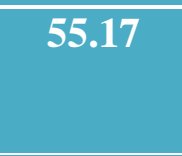 \\
\hline 5. & $\begin{array}{l}\mathrm{ZnO} 15 \mathrm{~kg} / \mathrm{ha}(\mathrm{SA})+\text { Borax } 10 \mathrm{~kg} / \mathrm{ha}(\mathrm{SA}) \\
+ \text { Sulphar as basal + carbendazim + } \\
\text { mancozeb @ } 0.2 \% \text { (FS) } 2 \text { sprays }\end{array}$ & $9.37(17.81)$ & $1.40(6.79)$ & 5.39 & 32.94 \\
\hline 6. & $\begin{array}{l}\mathrm{ZnO} 15 \mathrm{~kg} / \mathrm{ha}(\mathrm{SA})+\text { Borax } 10 \mathrm{~kg} / \mathrm{ha}(\mathrm{SA}) \\
+ \text { Sulphar as basal dose + P. flurescens } \\
10 \mathrm{ml} / 1 \text { water }(\mathrm{FS})\end{array}$ & $2.77(9.51)$ & $0.40(2.96)$ & 1.59 & 80.26 \\
\hline 7. & $\begin{array}{l}\text { Removal of three lower leaf + Ridomil MZ } \\
72 \text { WP@ } 0.2 \%(\text { FS })\end{array}$ & $0.67(4.53)$ & $2.70(7.13)$ & 1.69 & 79.02 \\
\hline 8. & $\begin{array}{l}\text { Ipridione + carbendazim } 2 \mathrm{~kg} / \mathrm{ha}(\mathrm{ST})+ \\
\text { Removal of three lower leaves. }\end{array}$ & $2.03(8.09)$ & $1.33(6.61)$ & 1.68 & 79.08 \\
\hline 9. & Propiconazole@ 0.1\% (ST)+(FS) & $0.87(5.10)$ & $3.80(11.23)$ & 2.34 & 70.92 \\
\hline 10. & Control & $10.23(18.60)$ & $5.83(13.98)$ & 8.03 & \\
\hline & $\mathrm{CD}(\mathrm{P}=0.05)$ & 1.76 & 2.33 & & \\
\hline
\end{tabular}

Figures in parentheses are angular transformed values; ST: seed treatment; SA: Soil application; FS: foliar spray.

Similarly lowest Alternaria pod blight severity of 1.59 per cent pooled mean was recorded from treatment combination of $\mathrm{ZnO} 15 \mathrm{~kg} / \mathrm{ha}$ (Soil application) + Borax $10 \mathrm{~kg} / \mathrm{ha}$ (Soil application) + Sulphar as basal dose $+P$. flurescens $10 \mathrm{ml} / \mathrm{lit}$. Water (1 foliar spray) 1.59 per cent pooled mean was recorded minimum disease severity of two successive postmonsoon (rabi) crop seasons, followed by Ipridione + carbendazime $2 \mathrm{~kg} / \mathrm{ha}$ (ST) + Removal of three lower leaves 1.68 per cent and Removal of three lower leaf + Rridomil MZ 72 WP@ 0.2\%(FS) 1.69 per cent and gave highest per cent disease control, 80.26 per cent followed by 79.08 and 79.02 per cent as compared to other treatments respectively (Table 2). Soil applied sulphur was found to increase resistance against a variety of fungal pathogens on different crops (Klikocka et al., 2005). In Indian context, more than 50\% (10 $\mathrm{m} \mathrm{ha}$ ) of the agricultural soils is zincdeficient (Singh et al., 2005). Early sowing (Meena et al., 2002) of well-stored clean certified seed after deep ploughing, clean cultivation, timely weeding and maintenance of optimum plant population, avoidance of irrigation at flowering and pod formation stages may help to manage the disease. Mancozeb was the best among all the treatments, resulting in the lowest disease severity on leaves of mustard (Meena et al., 2004). Iprodione (Rovral) spray 
has been found effective in checking silique infection due to A. brassicae (Cox et al., 1983). Integration of several management practices viz., planting of cabbage in 01 November at 40 $x 40 \mathrm{~cm}$ spacing in the field treated with $\mathrm{S}-\mathrm{Zn}$ Mg-Mo-B at 30-5-1-1-1 kg ha-1 in addition to the recommended rate of NPK and sprayed with chemical fungicide Iprodione recorded the best Alternaria blight reduction and increased seed yield by over the normal management practices (Hossain and Mian, 2005). Our results of twoyear study comprehensively proved that combination of $\mathrm{ZnO} 15 \mathrm{~kg} / \mathrm{ha}$ (Soil application) + Borax 10kg/ha (Soil application) + Sulphar as basal dose $+P$. flurescens $10 \mathrm{ml} /$ lit. Water (1 foliar spray) as effective substitutes for mancozeb for better control of disease in Indian mustard crop.

\section{References}

Abbott's, W.S. 1925. A method of computing the effectiveness of an insecticide. J. Eco. Ent., 18: 265-267.

Agrios, G.N.: Plant pathology, 5th Edn. 2005. Elsevier Academic Publishers, California, USA, p. 922

Bandopandopadyay L, Basue D, Sikdar SR. 2013. Identification of genes involved in wild Crucifer Rorippa indica resistance response on mustard aphid Lipaphis erysimi challenge.PLoSOne8: 73632.

Conn, K.L., J.P. Tewari and R.P. Awasthi. 1990. A disease assessment key for Alternaria black spot in rapeseed and mustard. Canadian Plant Disease Survey, 70, 19-22.

Cox, T., Souche, J. L. and Grapel, H. 1983. The control of Sclerotinia, Alternaria and Botrytis on oilseed rape with spray treatments of flowable formulation of iprodione. Abstr. 6th Int. Rapeseed Congr, Paris, France, 17-19 May 1983, pp. 928-933.

FAO: Food and agricultural commodities production. (2010). In: http://www. faostat.fao.org/site/339/default.aspx downloaded on 12 Apr 2010, 1226 hrs IST.

Hossain, M.S. and H. Mian., 2005. Integrated approach for the management of Alternaria blight of cabbage seed crop. Bangladesh J. Plant Pathol., 21, 19-23.

Klikocka, H., S. Haneklaus, E. Bloem and E. Schnug. 2005. Influence of sulphur fertilization on infection of potato tubers with Rhizoctonia solani and Streptomyces scabies. J. Plant Nutrition, 28, 819-833.

Meena, P.D., Chattopadhyay, C., Singh, F., Singh, B. and Gupta, Ajit. 2002. Yield loss in Indian mustard due to white rust and effect of some cultural practices on Alternaria blight and white rust severity. Brassica, 4: 18-24.

Meena, P.D., Meena, R.L., Chattopadhyay, C. and Kumar, Arvind. 2004. Identification of critical stage for disease development and biocontrol of Alternaria blight of Indian mustard (Brassica juncea). J. Phytopathology, 152: 204-209.

NRCRM. 1999. Package of practices and contingency plan for enhancing production of rapeseed-mustard. National Research Centre on Rapeseed-Mustard, Sewar, Bharatpur 321303, India. p.39.

Singh, B., S. Kumar, A. Natesan, B.K. Singh and K. Usha. 2005. Improving zinc efficiency of cereals under zinc deficiency. Current Sci., 88, 36-44.

\section{How to cite this article:}

Netam, R.S., S.C. Mukherjee, J.L. Salam and Netam, P.S. 2018. Management of Alternaria Leaf and Pod Blight Diseases of Mustard through Combination of Bio-Agents, Fungicides, Micronutrients and Cultural Operations in Bastar Plateau of Chhattisgarh. Int.J.Curr.Microbiol.App.Sci. 7(11): 1239-1243. doi: https://doi.org/10.20546/ijcmas.2018.711.144 